7. Reprod. Fert. (1970) 23, 521-523

\title{
HYALURONIDASE IN HUMAN SEMEN AND SPERM SUSPENSIONS SUBJECTED TO TEMPERATURE SHOCK AND TO FREEZING
}

\author{
D. R. AGKERMAN \\ Laboratory of Physical Anthropology, Department of Anthropology, \\ University of California, Los Angeles, California 90024, U.S.A.
}

(Received 30th Fuly 1970)

The enzyme hyaluronidase is believed to permit spermatozoa to disperse or to penetrate the cumulus oophorus (Kurzrok, Leonard \& Conrad, 1946; Swyer, 1947a; Austin, 1948). The mechanism by which hyaluronidase mediates fertilization may not be the same in all species; Swyer (1947b) has discussed the release of enzyme by spermatozoa as a function of cell concentration, and of hyaluronidase concentration in the suspending medium. He noted that spermatozoa appear to be diffusing preformed hyaluronidase, and not to produce the enzyme. This was also the finding of Bergenstal \& Scott (1948). It is well established for several species including man (Bergenstal \& Scott, 1948) that hyaluronidase is a product of the seminiferous epithelium (Swyer, $1947 \mathrm{~b}$ ), and associated with spermatozoa, not with the accessory reproductive organs. In particular, the cellular enzyme was shown to occur in the sperm heads (Masaki \& Hartree, 1962), and further investigation by Stambaugh \& Buckley (1969) has shown that hyaluronidase is localized in the acrosome.

Recent work has established that a tubal factor operates during fertilization as well, and that this is the bicarbonate ion (Stambaugh, Noriega \& Mastroianni, 1969). In addition, it has become clear that hyaluronidase is not the only factor involved in the penetration by spermatozoa of cumulus, corona or zona pellucida. A trypsin-like enzyme (Stambaugh \& Buckley, 1969; Stambaugh, Brackett \& Mastroianni, 1969), and a corona-penetrating enzyme (Zaneveld \& Williams, 1970) have been identified, and are also associated with the acrosome. Allison \& Hartree (1970) have suggested that the acrosome releases its enzymes sequentially, hyaluronidase being active at the preliminary, cumulus-penetrating stage of fertilization.

The fertility of frozen-preserved human semen is substantially less than that of fresh semen, when used for clinical insemination (Behrman \& Sawada, 1966). A possible explanation for this finding is that hyaluronidase activity is altered by exposure to cryogenic treatment, or that ultra low storage temperatures alter the rate of diffusion of the enzyme from spermatozoa to the suspending medium. The only information bearing on this question shows that rabbit spermatozoa suspended in distilled water pass into solution a doubled amount of hyaluronidase when the suspensions are cooled to $0^{\circ} \mathrm{G}$ or frozen at $-10^{\circ} \mathrm{C}$ before the assay; freeze-drying produces the same result (Swyer, 1947b). 
In order to examine this question, a total of ten semen specimens was obtained from three donors. Each specimen was divided into two parts; one part was diluted to five times its original volume in Mann's Ringer solution (Mann, 1964), containing $15 \% \mathrm{v} / \mathrm{v}$ glycerol; the second portion was centrifuged at 600 to 1000 RCF to separate the cells from the seminal plasma. The cells were washed once in Mann's Ringer solution, and were then resuspended to five times the volume of the original aliquot in Mann's Ringer solution with $7.5 \%$ $\mathrm{v} / \mathrm{v}$ glycerol. Thus, the final concentration of glycerol in each suspension was $7.5 \%$ by volume (Sawada \& Ackerman, 1968). The two aliquots were then further subdivided to provide one set of samples which was subjected to no further treatment, one set which was cooled to $0^{\circ} \mathrm{C}$ at the rate of $1.5^{\circ} \mathrm{C} / \mathrm{min}$, and a set which was cooled to $-196^{\circ} \mathrm{C}$ at an average rate of $200^{\circ} \mathrm{C} / \mathrm{min}$.

TABLE 1

HYALURONIDASE CONTENT OF WASHED GELL SUSPENSIONS AND OF WHOLE SEMEN, $\mu \mathrm{G} / 0.25 \mathrm{ML}$, \pm S.E. OF MEAN

\begin{tabular}{l|rr|rr|rr}
\hline & \multicolumn{2}{|c|}{ Untreated } & \multicolumn{2}{|c|}{ Temperature-shocked } & \multicolumn{2}{|c}{ Frozen, $-196^{\circ} \mathrm{C}$} \\
& $0 \mathrm{hr}$ & $2 \mathrm{hr}$ & $0 \mathrm{hr}$ & $2 \mathrm{hr}$ & $0 \mathrm{hr}$ & $2 \mathrm{hr}$ \\
\hline Washed & 2.96 & 2.68 & 2.66 & 2.69 & 2.75 & 2.81 \\
cells & \pm 0.20 & \pm 0.11 & \pm 0.11 & \pm 0.06 & \pm 0.08 & \pm 0.11 \\
Whole & 2.63 & 2.60 & 2.61 & 2.62 & 2.69 & 2.76 \\
semen & \pm 0.05 & \pm 0.06 & \pm 0.05 & \pm 0.06 & \pm 0.05 & \pm 0.06 \\
\hline
\end{tabular}

TABLE 2

VARIANCE ANALYSIS, HYALURONIDASE ( $\mu \mathrm{G} / 0.25 \mathrm{ML}$ ), TEMPERATURE TREATMENTS VERSUS WASHED CELLS AND WHOLE SEMEN

\begin{tabular}{l|r|c|c|c}
\hline \multicolumn{1}{c|}{ Source of variation } & $f$ & Sums of squares & Mean squares & $F$ \\
\hline Total & 119 & 11.123 & & \\
Between subclass & 5 & 0.738 & & \\
Treatments & 2 & 0.240 & 0.120 & 1.32 \\
Washed cells-Whole semen & 1 & 0.346 & 0.346 & 3.81 \\
Interaction & 2 & 0.152 & 0.076 & 0.84 \\
Error & 114 & 10.385 & 0.091 & \\
Error, with interaction SS & 116 & 10.537 & 0.091 & \\
\hline
\end{tabular}

Enzyme present, expressed as $\mu \mathrm{g} / 0.25 \mathrm{ml}$ sperm suspension, was determined at this point and again after $2 \mathrm{hr}$ incubation at $35^{\circ} \mathrm{C}$, by means of the colorimetric method of Greif (1952). Values for hyaluronidase as nitrogen were computed on the basis of amount of enzyme required to reduce $20 \mu \mathrm{g}$ hyaluronic acid $/ 0 \cdot 25$ $\mathrm{ml}$ by one-half. This amount was determined to be $5.0 \mu \mathrm{g}$, and is one-half the value employed by Kurzrok et al. (1946).

Results of these experiments are given in Table 1. No significant differences are found between the initial and the 2-hr values. For purposes of additional analysis, the two sets were combined. Two-way variance analysis indicates that no differences exist among temperature treatments or between washed cells and whole semen, and that there is no interaction between treatments. 
In most respects the tabulated values for hyaluronidase are consistent with those previously reported. This indicates that the cooling procedures employed in providing for the long-term storage of human semen prevent alterations from occurring in the release and activity of an enzyme which is of importance in effecting fertilization. Although current practices do not prevent damage in frozen-thawed spermatozoa, it is clear from reports on the unprotected freezing of these cells (Swyer, 1947b; Perlman, Leonard \& Kurzrok, 1948) that glycerol is necessary in preserving normal hyaluronidase activity. It is confirmed that spermatozoa liberate preformed hyaluronidase soon after ejaculation, and that no enzyme is produced during the course of incubation (Swyer, 1947b; Bergenstal \& Scott, 1948). The amounts of hyaluronidase measured in these experiments were not clearly associated with sperm concentration, and variances in hyaluronidase content among specimens within donors are small.

This work was supported by Grant HD 02592, National Institutes of Health.

\section{REFERENGES}

Allison, A. G. \& Hartree, E. F. (1970) Lysosomal enzymes in the acrosome and their possible rôle in fertilization. 7. Reprod. Fert. 21, 501.

Austin, G. R. (1948) Function of hyaluronidase in fertilization. Nature, Lond. 162, 63.

Behrman, S. J. \& Sawada, Y. (1966) Heterologous and homologous inseminations with human semen frozen and stored in a liquid-nitrogen refrigerator. Fert. Steril. 17, 457.

Bergenstal, D. M. \& Scott, W. W. (1948) Studies on hyaluronidase. F. Am. med. Ass. 137, 1507.

GREIF, R. L. (1952) Colorimetric determination of hyaluronidase activity. F. biol. Chem. 194, 619.

KuRzROK, R., LEONARD, S. L. \& ConRAD, H. (1946) Rôle of hyaluronidase in human infertility. Am. F. Med. 1, 491.

ManN, T. (1964) The biochemistry of semen and of the male reproductive tract. Wiley, New York.

MASAKr, J. \& HARTREe, E. F. (1962) Distribution of metabolic activity, phospholipid and hyaluronidase between the heads and tails of bull spermatozoa. Biochem. F. 84, 347.

Perlman, P. L., Leonard, S. L. \& Kurzrok, R. (1948) Some factors influencing the liberation of hyaluronidase from testes homogenate and spermatozoa in the rat. Endocrinology, 42, 26.

Sawada, Y. \& Ackerman, D. R. (1968) The use of frozen-preserved human semen. In: Progress in Infertility. Eds. S. J. Behrman and R. W. Kistner. Little, Brown, Boston.

Stambaugh, R., Brackett, B. G. \& Mastrotanni, L. (1969) Inhibition of in vitro fertilization of rabbit ova by trypsin inhibitors. Biol. Reprod. 1, 223.

Stambaugh, R. \& Buckley, J. (1969) Identification and subcellular localization of the enzymes effecting penetration of the zona pellucida by rabbit spermatozoa. F. Reprod. Fert. 19, 423.

Stambaugh, R., Noriega, G. \& Mastroianni, L. (1969) Biocarbonate ion; the corona cell dispersing factor of rabbit tubal fluid. F. Reprod. Fert. 18, 51 .

SwYEr, G. I. M. (1947a) The hyaluronidase content of semen. Biochem. F. 41, 409.

SwYER, G. I. M. (1947b) The release of hyaluronidase from spermatozoa. Biochem. 7. 41, 413.

Zaneveld, L. J. D. \& Williams, W. L. (1970) A sperm enzyme that disperses the corona radiata and its inhibition by decapacitation factor. Biol. Reprod. 2,363 . 